\title{
The Comparison of the Baroque and Renaissance Aesthetics Paintings of "The Last Supper" by Caravaggio and Leonardo da Vinci
}

\author{
I Wayan (Kun) Adnyana \\ Institut Seni Indonesia (ISI) Denpasar \\ Jalan Nusa Indah, Denpasar 80235
}

\begin{abstract}
The paintings of Caravaggio's and Leonardo da Vinci's The Last Supper are two iconic artworks from two maestros in a different era. Caravaggio is one of the fame Baroque's artists and da Vinci is the most famous Renaissance man, who created the same theme of a painting, The Last Supper. The theme represents the story of Christ's supper. Through an inductive view, this comparative study analyzes the aesthetic structures of both paintings, by using Feldman's perspective in Art as Image and Idea (1967). The analysis includes visual structures, including line, form, darkness-lightness; elements of the organization, including unity, balance, rhythm, and proportion; and elements of perception and aesthetic, including empathy and a psychic distance. The result of this research discovers two different perspectives of aesthetic characteristics of Baroque and Renaissance paintings.
\end{abstract}

Keywords: baroque, Caravaggio, Leonardo da Vinci, renaissance, the last supper

\section{INTRODUCTION}

As revealed by Herr Osborn that the baroque, in his dark and heavy voice, expresses the heavy, prominent, and somewhat overwhelming forms, which must be forced to move to express his impression (Read, 2000: 76). The Baroque has the origin of two languages, namely the Portuguese, barroco, means a type of large rough pearls used for full ornament body of jewellery on those days, and the Italian, barocco, means any system of transformed, irrational, or impure thoughts. However, how the term became commonly used to name the art at that time was a mystery. The word of 'baroque' comes with a deviation of understanding, which originally had an odd form, then evolved into the notion of all things that are illogical, vague and magical/ odd (Read, 2000; Gowing, 2002).
There are two directions that can bring the art of abandonment. The first way is the path in which classical art passed through, the direction toward idealism (in proportions, harmony, and beauty). The other way is the path to a tendency that denies reality, a contradiction of the laws and the raisons d'etre of that reality (Read, 2000: 77). Therefore, it is believed that the Baroque art was born in the tension of deviation of the second direction, that is to realize the reality of beauty from the denials of reality over the beauty of its past; or toward the distant ideal beauty from the ideal beauty of the Renaissance. Although those directions have succeeded in giving aesthetic pleasure, as history has recorded, both as a part of the superiority of civilization that can be trampled by humans.

The Renaissance positions its aesthetic basis on humanism. Ideality is interpreted 
as an effort to honour and respect human rationality. The Renaissance artwork shows the processing of rationality and worshiping the subject (creator) as the center, which gradually perfects itself from the power of the church, as Baroque art - in the context of renewing the power of Roman Catholic Church from Protestant resistance carried by Martin Luther's in Germany in which the influence has affected to the North. It is a reflection of counter-reformation of the Church in making art as a part of propaganda. To re-preserve the dignity of the Church is carried out by reconciling on the expression of the pleasures of life (Gowing, 2002: 696).

Historically, the term 'baroque' was used in the nineteenth century to declare 17th-century painters who neglected or opposed the postulates of the beauty of classical art, and especially to sculptors and architects who favored the choice of forms, excessive and eccentric forms (Gowing, 2002: 696).

As an illustration, in Michelangelo's work, which is considered as the father of Baroque art, especially in a typical building art, such as the tombs of Giuliano de Medici in S. Lorenzo, Florenzo and the portal of the Laurentius Library in the same city, will be found architectural compositions of various parts (poles, windows, flat frames on the pole), which are no longer assumed as structural tasks, but merely used for aesthetic effects. In other words, the architectonic composition does not follow the laws of architecture, but rather the laws of art and sculpture (Read, 2000: 77).

At the end of the sixteenth century, Italy established an academy of painting led by Zuchero of Rome. The students' works at this academy were influenced by Michelangelo and Rafael. Similarly outside Italy, many academies were built, among others in the city of Bologna led by Denys Colvoert, and in Antwerp led by famous fig- ure Caracci (Hadiatmodjo, 1990: 54). As a result, from these academies, the influence of the Baroque art spread inducing the birth of painters with confirmation the change of the classical style. Likewise, the emergence of painters Frederico Baroccio, Caravaggio, then later influenced Rubens, Jordaens, and others. While in the Netherlands, the work influenced the work of Frans Hals; and in Germany, it was influenced on the painter Elsheimer (Hadiatmodjo, 1990: 54).

This illustration at least brings us closer to a more extensive reading of the aesthetic of the Baroque art, which, in turn, identifies the specific characters of this art, if it is compared to the visual aesthetics of the Renaissance art. As an attempt to examine the aesthetic comparison between the Baroque and the Renaissance, the authors conducts a comparative study of "The Supper at Emmaus" painting by the Italian Baroque artist, Caravaggio (1573-1610), as the most ideal example of naturalistic painting in the early 17th century, and "The Last Supper" by Leonardo da Vinci, the most famous maestro of the Renaissance.

The selection of paintings from those two artists is based on the consideration that the theme of "The Last Supper" is one of the most inspiring themes for artists, both in the eras of Renaissance and Baroque. Besides, both are the two leading artists of their era. Of course, this selection is expected to bring the author to explore the aesthetic characteristics of each era inductively. At the end, it is formulated in conclusion based on the comparison of the small parts of the visual structure of the two works.

\section{METHOD}

In this comparative study, the author uses reproduction photos of "The Supper at Emmaus" (oil on canvas; 141X196 cm), Caravaggio's work published in A History of Art by Sir Lawrence Gowing, 2002, Oxfordshire, England: Oxford Limited, p. 695. The 
work is compared to Leonardo da Vinci's 'The Last Supper', 1495-1497 (oil and tempera on masonry, 422X904 cm), published in Encarta Encyclopedia, 2005; Art in FocusLeonardo da Vinci, 2005, (English edition): Konemann, p. 45, by Elke Linda Buchholz.

Although there is a possibility of reduction to details of works because of reading and examining data from the reproduction version of the book rather than observing the original works, compared to the method presented by the author. However, the author believes that the visual structures of these two works should not be changed, even in the form of reproduction photographs. Therefore, the comparison model used as reference is the comparison model of structures; all of which are visual elements of art that can be easily recognized through observing. Thus, in this context, the choice of comparative study based on reproductive photographs does not violate the procedure of scientific studies.

For the study of structure in this paper, the author borrows the theory of Edmund Burke Feldman in Art as Image and Idea (1967). The structure is expressed in the division of visual elements, such as line, shape, and light dark; organizing elements including unity, balance, rhythm, and proportion; and the last, about the elements of perception or aesthetic, in the form of empathy and psychical distance. Through this polarization approach, the two works of "The Last Supper" are analyzed.

The research employs a qualitative method using descriptive analysis. The measures that are taken using the taste of sensing analysis is qualitative visual aesthetic. This includes formulating all aesthetic views (discourses) about the two works that have been written by some experts and historians. This means that the analysis of the visual structures are also deliberated by the views of the discourses surround the works, especially related to the aesthetic discourses which become important references in expanding the analysis.

\section{RESULTS AND DISCUSSION}

The discussion is divided into two stages: first is the identification of the visual structures based on the contents following the pattern of Feldman's visual structure division; second is the synthesis formulation/analysis. Identification is a short description, which describes the character of each part of the structures. Synthetic analysis develops the short description with argumentative, narrative, and also referential descriptions. In the synthetic analysis stage, the results of the description are formulated with the views or discourses surrounding the work.

The descriptions are arranged specifically for each work as the subject of study, namely "The Last Supper" version of Caravaggio, and then da Vinci's work. The important thing in each section of the discussion is then formulated in conclusion; so it will be easy to see the Baroque aesthetic differences with Renaissance.

\section{“The Last Supper" by Caravaggio}

Caravaggio is an Italian Baroque painter, in which his real name is Michelangelo Merisi. He was born on September 28, 1573, in the Lombardia, part of the town of Caravaggio --which later became his popular name (Sullivan in Encarta Encyclopedia, 2005). Caravaggio is a painter with a strong personality and revolutionionist, who painted naturalism with the theme of daily life objects, the content of history, and the content of scripture (Hadiatmodjo, 1990: 54).

In the category of depictions of this holy book, Caravaggio painted a work entitled "The Supper at Emmaus" (oil on canvas; $141 \mathrm{X} 196 \mathrm{~cm}$ ) that estimated being made in 1596/8-1602, or nearly a century after Leonardo da Vinci completed "The Last Supper" in 1497. This work was featuring only 


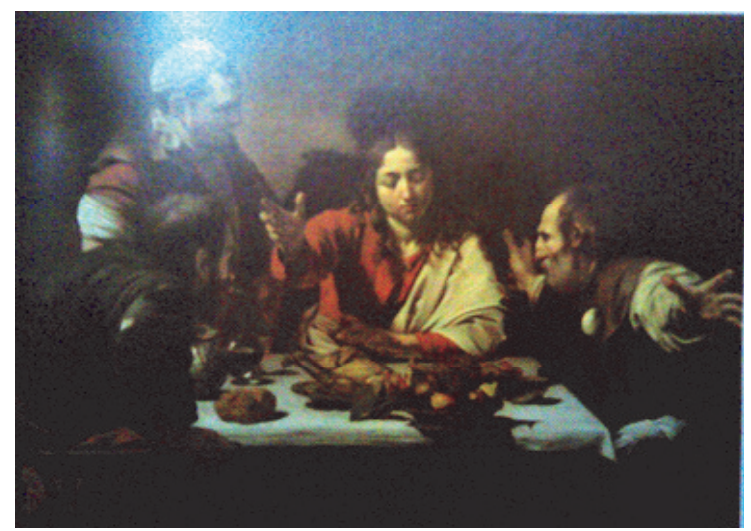

Work "The Supper at Emmaus" (oil on canvas; 141 X196 cm) by Caravaggio, taken from Gowing, A History of Art (2002: 695)

four subject images, one of which is a picture of Jesus who is turning toward the food on the table, while his right-hand points forward. While the three disciples of Jesus are on the side, two of them are listening to Jesus' words, and the other was arguing -though in the condition of his mouth was unopen- clearly visible from the expression and gestures of his hands, he spoke enthusiastically with Jesus.

The following is an analysis of the visual elements of each structure of the works:

\section{a. The Identification of Visual Elements}

\begin{tabular}{ccc}
\hline \multicolumn{1}{c}{ Lines } & \multicolumn{1}{c}{ Form } & Light-Dark \\
\hline$\bullet$ unidentified & $\bullet$ Naturalistic & $\bullet$ Contrast \\
$\bullet$ no more au- & $\bullet$ Strong cha- & and strong \\
tonomy & racters & $\bullet$ Dramatic \\
& B Brings up & $\bullet$ There is a \\
& the impres- & shadow \\
& sion of dia- & \\
& logue & \\
\hline
\end{tabular}

The identification of this visual element structure can be described as follows: Caravaggio's "The Supper at Emmaus" prioritizes the appearance of the shape (the subject of the image) towards characterizing character and raising dramatically the person in the discussion even though it is done at the dinner table. The scattered foods on the table are the parts that they invited to dialogue with. In this case, dialogue takes precedence over the issue of enjoying the food itself. The subject's image, as well as the dramatic character of a serious dialogue, is achieved by weighing the dramatization on the light-dark.

\section{b. The Identification of Organisational Elements}

\begin{tabular}{llcl}
\hline Unity & Balance & Rhythm & Proportion \\
\hline$\bullet$ View & $\bullet$ Asym & $\bullet$ Dyna- & $\bullet$ Naturalis- \\
Fo- & metrical & mic & tic. \\
cus & $\bullet$ Diagonal & $\begin{array}{c}\bullet \text { Inter- } \\
\text { active }\end{array}$ & $\bullet$ Character \\
\hline
\end{tabular}

Through the table above, it can be described as follows: the harmonious unity of this work is extracted from the formulation between the proportional model of the natural image subject and the emphasis on the attainment of the character expression (face). Similarly, it is depicted by the diagonal image distribution of the subject; one is standing, one (Jesus) seems to move from the seat, and the other two remains seated. Dynamism is also achieved from the hand gestures and gazes subjects focus on the figure of Jesus, to the thematic unity; Jesus as the main character in this story can be achieved without having to make it massive and symmetrical. It means that our view to focus (Jesus) is emphasized by the intensity of the dynamic composition to this focal point. Our view is directed naturally and slowly.

Through the pattern of organizing element, Caravaggio achieves the dramatic strength of "The Supper at Emmaus," which focuses on the appearance of strong subject characters by revealing contrasting lights but still poetic. Similarly, this work gives a condition of how Caravaggio dares to play with non-symmetrical diagonal composition, so the flow of this composition suggests that the subject is really in the story that is in dialogue. 
c. The Identification of Perception or Aesthetic Elements

\begin{tabular}{ll}
\hline Empathy & Psychic Distance \\
\hline The connoisseur of & The psychic closeness \\
the work becomes & of connoisseurs are \\
part of the dramatic & awakened in the dra- \\
work; & matic, naturalistic and \\
$\begin{array}{l}\text { Einfuhlung/feeling } \\
\text { into }\end{array}$ & poetic story \\
\hline
\end{tabular}

The analysis on the table of perception element structure deeply places the appreciators on an inseparable position with the artist perception in creating the artwork. It means that the impression to be built over the work through observer perception is a part that has been conceptually designed by the artist. The identification of the perception element structure will reveal the concept of the artist, which may have never been opened to the public.

The elements of perception or aesthetics are concerned with the interpretation of the connoisseur. Of course, in this context is the author. This description also presents other observer's explanations to complement (at least find the point of similarity of the argument), so that it does not appear to be absolute subjectivity. Caravaggio's work must be acknowledged to be able to bring the atmosphere of Einfuhlung/feeling into for the connoisseurs; lovers seem to be part of the dialogue that occurs on the dinner table. It is a work that contains the dramatic enthusiasm of each subject, the image toward Jesus makes a poetic focus of view, which builds deep psychological connection on the connoisseur feelings of this work.

Sir Lawrence Gowing, in his book $A$ History of Art (2002), writes that in general -does not refer only to the work of "The Supper at Emmaus"- Caravaggio with his realistic psychology is able to tell the rhetoric of the scriptures (Bible); his work suggests the power and in irrational contrasts of light, depictions of shadows in poetic depths, and allowing some empty space, indeed presents dramatic scenes (Gowing, 2002: 697).

This means that there is a point of connection to explain that Caravaggio's work has manifested itself as an artwork which the capablility of inflaming church rhetoric, translating scriptural content by placing how ordinary people preach and perceive the "Last Supper" event, as a dramatic event. How Jesus revealed, "there will be among you who betray me." This atmosphere is recalled by dramatically-naturalistic Caravaggio, which according to Gowing is called as the psychology of realism.

\section{Leonardo da Vinci's "The Last Supper"}

Leonardo da Vinci was born at 10:30 pm, on Saturday, April 15, 1452. His mother, Chaterina was a farmer from Anchiano, a small village near the town of Vinci, about 40 miles from Florence. His father, Ser Piero da Vinci, who did not marry his mother, was a rich notary and accountant in the city of Florence. Leonardo was taken by his grandfather to be educated at his house, until he finally sent Leonardo to an artist studio of Andre Del Verrocchio (1435-1488). Because of Leonardo's specialty in painting, Verrocchio finally stopped to paint (Gelb, 2001: 25-27).

Leonardo then grew up as the most influential artist of the European Renaissance. Some of his masterpieces were born as human civilization icons of beauty. For example, the works of "Mona Lisa" (15031506), "The Madonna of The Rocks" (14831490), and also included "The Last Supper" (1495-1497), size 422x904 cm (oil and tempera on masonry), are painted on the wall of the restaurant of Santa Maria Delle Grazie, Milan. This last masterpiece was just completed in 1999. 


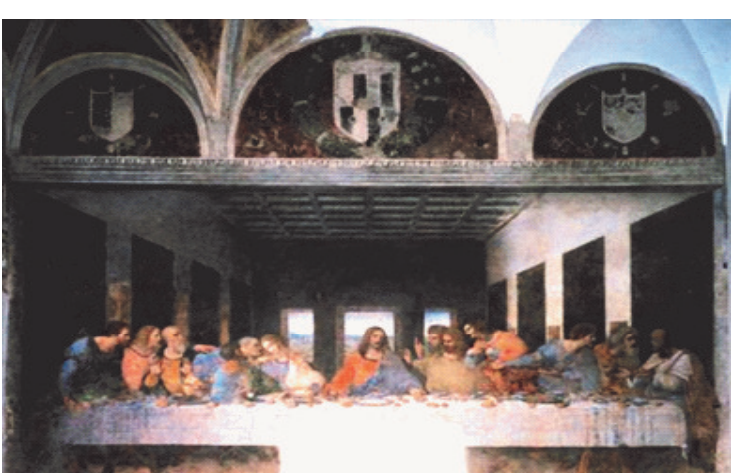

"The Last Supper" by Leonardo da Vinci (1495-1497), taken from Buchholz, Art in Focus-Leonardo da Vinci (2005: 45).

The identification of the structure of Leonardo's "The Last Supper" is as follows:

\section{a. The Identification of Visual Elements}

\begin{tabular}{lll}
\hline \multicolumn{1}{c}{ Lines } & \multicolumn{1}{c}{ Form } & Light-Dark \\
\hline - Identi- & $\bullet$ Naturalistic & $\bullet$ Equal to all \\
fied & $\bullet$ Strong charac- & image sub- \\
in the & ters & jects \\
back & $\bullet$ Brings up the & $\bullet$ without \\
ground & $\begin{array}{l}\text { impression of } \\
\text { dialogue }\end{array}$ & shadow \\
& dialow \\
\hline
\end{tabular}

From this identification, it can be described as follows: Leonardo da Vinci's "The Last Supper" creates a strong character identity on each subject. It includes how the gestures of Jesus' disciples who sit in the rows of the long table, suggests how a dialogue/discussion takes place warmly. With a static dark-light emphasis; almost all subjects are exposed to light in the same intensity, making the expression not conical at one focus; on how Jesus said there would be betrayers. Likewise, with no contrast, the scene becomes less dramatic. While the use of horizontal lines on the ceilings and also on the window/openings tends to be rigid/ massive; making the scene of the "Last Supper" is less dynamic.

\section{b. The Identification of Organizational Element}

\begin{tabular}{cccc}
\hline Unity & Balance & Rhythm & Proportion \\
\hline$\bullet$ cen- & $\bullet$ Symet- & $\bullet$ Rigid/ & $\bullet$ Naturalis- \\
tral & $\begin{array}{l}\text { rical } \\
\text { mathe- } \\
\end{array}$ & $\begin{array}{l}\text { mas- } \\
\text { sive }\end{array}$ & $\bullet$ tic. \\
& matical & & \\
\hline
\end{tabular}

Based on the above table, the identification of organizing elements can be described as follows.

This work tends to build the unity of the subject matter and other symbols, such as the scattered foods on the table, the table itself, and the background that lies at one central point; Jesus sits in the middle, then other subjects line up sideways rigidly, symmetrically and in the count of the number of very mathematical elements. Six subjects are on the right side, and six on the left. The direction of perspective is also conical toward Jesus, with the window open behind him. In particular, the middle table that horizontally plays out, as a boundary determinant, must be unhindered by anything. This adds to the symmetrical and rigid impression of Leonardo's "The Last Supper" work.

\section{c. The Identification of Perception and Aes- thetic Elements}

\begin{tabular}{ll}
\hline Empathy & Psychic Distance \\
\hline The connoisseur per- & The psychic closeness of \\
ceives that the work the audience is awak- \\
is outside of him. But ened by the natural- \\
the expression ef- istic tale of the story. \\
fects and the subject However, it does not \\
character make the make the audience in a \\
connoisseurs admire provoked condition. \\
it (sympathy).
\end{tabular}

The identification of a perceptual or aesthetic element of Leonardo's work puts the audience on a tremendous sense of awe. Leonardo conveyed his characters intricately in details towards the thirteen drawings depicted beside the dining table make their gestures are full of inspirations. By a static composition, however, the connoisseur is separated by the rigid long table drawing, as if explaining that the "Last Supper" dialogue becomes as far away - it is in the scriptures until it is not a psychological part of the connoisseur anymore.

Gelb states that "The Last Supper" allows an observer to capture the most stun- 
ning visual metaphor. Leonardo's admiration for the ripples emerging from the stone thrown into the pond manifested in his circle motives; the disciples surrounded the very quiet figure of Christ in a semicircle, all the objects on the plates, bread, and glass shaped a circle. Just as a stone is thrown into the pool of immortality, Leonardo illustrates the spreading influence of Christ to change the human destiny forever (Gelb, 2001: 31).

Leonardo's "The Last Supper" painting shows more mathematical considerations, both in managing the composition, and how he intends to make Jesus the center. Historian E.H. Gombrich states that the work of "The Last Supper" is one of the great wonders of human genius (Gombrich in Gelb, 2001: 32). This creates that an impression on the mind of the connoisseur is just a sense of awe and amazement. On the contrary, it does not suggest the audience to be part of the story in this work. That's because the work is positioned as an entity outside of self; more on the ethical functions that lead to logic conceptually.

\section{CONCLUSION}

This comparative study reveals that Caravaggio's work “The Supper at Emmaus" emphasizes on how the "Last Supper" scene is told to bring the story taken from the Bible closer to the audience, so dramatization is the main desire of the painter. Thus, the visualization of "misbehaviour" is born, such as setting the subject of the image diagonally, maintaining the dynamic impression and the naturalistic image of the subject characters.

On the other hand, Caravaggio is also very brave to build a contrast, which seems very irrational; how light only sweeps on very narrow parts of the body (body surface); there should be only one direction of light, the rest is pitch black. This contrast, of course, builds a tremendous dramatic impression, which is able to invite the intuition of the connoisseur to enter into the intense situation.

"The Last Supper" created by Leonardo da Vinci prefers a definite beauty. The beauty incarnated from the mathematical calculations. Conversely, taste and empathy are not important considerations. Thus, his work is remarkably admired as a work of genius. Because of its symmetrical, rigid and more mathematical considerations in the arrangement of the subject line of the picture (composition), the connoisseur is exposed to the psychic distance to the work.

In this comparative study, it can be formulated inductively that Baroque artwork emphasizes more to how it psychologically capable to suggest the connoisseur's empathy for the work. While visually, the composition is more dynamic (via a diagonal pattern), with dramatic dark contrasts, and naturalistically still tells the character of the subject matter. Meanwhile, Renaissance painting is more concerned with visual beauty with the consideration of mathematical visualization, symmetrical composition, and with non-extreme of dark-light. Connoisseurs more emphasis on the awe of the beauty of visual works rather than the emergence of empathy.

\section{Bibliography}

A. Hadiatmodjo Supardi

1990 Sejarah Seni Rupa Eropa. Semarang: IKIP Semarang Press.

Buchholz, Elka Linda

2005 Art in Focus-Leonardo da Vinci. Cambridge: Konemann.

Feldman, Edmund Burke

1967 Art as Image and Idea. Englewood Cliffs, New Jersey: Prentice-Hall Inc.

Gelb, Michael J.

2001 Menjadi Jenius Seperti Leonardo Da 
Vinci (Penerj. T. Hermaya). Jakarta: Gramedia Pustaka Utama.

Gowing, Sir Lawrence

2002 A History of Art. Oxfordshire, England: Oxford Limited.
Read, Herbert

2000 Seni: Arti dan Problematikanya (Penerj. Soedarso SP.). Yogyakarta: Duta Wacana University Press.

Sullivan, Edward J.

2005 "Caravaggio" in Encarta ${ }^{\circledR}$ Reference Library. 